\title{
KEBERADAAN PENARI LAKI-LAKI PADA TARI JOGI
}

\author{
Restu Gustian Asra, Denny Eko Wibowo \\ Program Studi Seni Tari, Fakultas Seni, Universitas Universal Batam \\ Email: restuugustian09@gmail.com,denny.wibowo84@gmail.com
}

\begin{abstract}
This article discusses the existence of male dancers in the presentation of the Jogi dance. Jogi dance is a dance originating from Batam, where the presentation of the dance movements is dominated by the technique of shaking the shoulders and noticeable hip movements. The variety of movements in the Jogi dance is referred to as duplicate related to the daily activities of the Batam people as fishermen. Applying a qualitative research method with interviewing techniques for Jogi dancers and observing the events of the Jogi performance, the discussion in this article covers the beginning of the appearance of male dancers and their development in supporting the choreography and function of Jogi dance in society. The analysis is carried out on the adaptation process carried out by male dancers in adjusting the motives of the movements of the female dancers that already exist first. The results show that the presence of male dancers in the choreography of the Jogi dance encourages new forms of presentation while finding new functions as part of a form of social action.
\end{abstract}

Keywords: Jogi Dance, Presentation Form, choreography, dance functions.

\begin{abstract}
ABSTRAK
Artikel ini membahas tentang keberadaan penari laki-laki dalam penyajian tari Jogi. Tari Jogi merupakan sebuah tari yang berasal dari Batam, yang penyajian gerak tarinya didominasi oleh teknik goyang bahu dan pergerakan pinggul yang kentara. Ragam gerak dalam tari Jogi disebut sebagai rangkap yang berkaitan dengan kegiatan sehari-hari masyarakat Batam sebagai nelayan. Menerapkan metode penelitian kualitatif dengan teknik wawancara terhadap para penari Jogi dan observasi atas peristiwa pertunjukan Jogi, pembahasan dalam artikel ini meliputi awal mula kemunculan penari laki-laki dan perkembangannya dalam mendukung aspek koreografi serta fungsi tari Jogi di masyarakat. Analisis dilakukan atas proses adaptasi yang dilakukan oleh para penari laki-laki dalam menyesuaikan motif gerak-gerak penari perempuan yang sudah ada terlebih dahulu. Hasil penelitian menunjukkan bahwa keberadaan penari laki-laki dalam koreografi tari Jogi mendorong bentuk penyajian baru sekaligus menemukan fungsinya yang baru sebagai bagian dari bentuk tindakan sosial.
\end{abstract}

Kata Kunci: Tari Jogi, Koreografi, Fungsi Tari. 


\section{PENDAHULUAN}

Kota Batam merupakan kota yang termasuk dalam Provinsi Kepulauan Riau, sehingga merupakan bagian dari daearah yang menjaga kelestarian seni budaya melayu. Beragam suku, adatistiadat, kebudayaan, bahasa dan agama berkembang di Kota Batam.

Salah satu seni pertunjukan yang khas dari Batam ialah tari jogi yang kemunculannya berasal dari kreativitas seniman asli Pulau Panjang bernama Basri. Tarian Jogi merupakan tarian khas dari daerah Batam sendiri tepatnya di Pulau Panjang. "Tarian ini menjadi kebanggan Batam karena tarian ini sudah dikenal baik di Nusantara maupun mancanegara". (Aziah, 2018) Rangsangan awal melalui iringan musik Jogi mendorong spontanitas yang berkelanjutan sehingga muncullah ragam-ragam gerak tari jogi dengan gerak dasar yang sering dijumpai dalam beberapa tarian melayu yaitu dasar gerak melenggang. Gerak tersebut cukup banyak digunakan dibeberapa tarian melayu seperti lenggang patah sembilan, joget dangkong, dll. Keberadaan tarian ini kini semakin berkembang sesuai dengan daya kresi para penari disesuaikan dengan peristiwa pementasannya. Munculnya kreativitas para pelaku seni di Batam tersebut kemudian menimbulkan pertanyaan tentang seberapa jauh kreasi tersebut dibuat dan bentuk penyajiannya yang tetap mengacu pada tari Jogi.Penulis pernah menyaksikan pementasan tari Jogi yang disajikan oleh penari perempuan, dan yang melibatan penari laki-laki. Perkembangan penyajian ini yang mendorong penulis menguraikan artikel tentang tari Jogi.

Tari Jogi merupakan kesenian masyarakat melayu masa lampau yang seringkali disampaikan sebagai gambaran interaksi para muda-mudi sehingga mudah dikenali sebagai tari hiburan di Batam. Hal ini tak lain karena peranan penting seniman tradisional (alm) Basri sekeluarga yang berasal dari pulau Panjang. Kepopuleran tari Jogi Batam hingga kini belum diimbangi dengan kajian dan informasi ilmiah yang mudah diakses oleh masyarakat luas, sehingga keberadaannya hanya diketahui melalui informasi ringan yang dapat ditemukan di internet, dan media sosial.

\section{METODE PENELITIAN}

Pertti Alasuutari via Soedarsono menjelaskan bahwa bahan penelitian kualitatif ibarat secuil dunia yang harus dicermati dari pada hanya mendapatkan seperangkat ukuranukuran. (Soedarsono, 1999). Maka dari itu, seorang peneliti harus melakukan pengamatan bahan-bahan tersebut dengan cermat kemudian menganalisisnya.

Peneliti juga menggunakan teknik pengumpulan data atau informasi yang dikumpulkan dan dianalisis dalam penelitian ini berupa data kualitatif. Teknik yang digunakan dalam penelitian ini meliputi beberapa teknik, yaitu analisis langsung, pencatatan, dan analisis dokumen yang terkait dengan objek penelitian, pendekatan, dan metode analisis data. untuk dijadikan sumber acuan peneliti pada penelitian ini.

Peneliti menggunakan metode kualitatif dalam bentuk deskriptif kualitatif, penelitian dalam bentuk deskriptif kualitatif ini studi kasusnya mengarah pada pendeskripsian secara rinci dan mendalam mengenai kondisi tentang apa yang terjadi sebenarnya. Yang dimana peneliti mencari 
informasi terkait penelitian ini dengan mewawancarai beberapa narasumber yang paham perihal tari Jogi, salah satunya adalah Normah yang merupakan maestro tari Jogi itu sendiri, serta beberapa pakar tari tradisi melayu, yaitu kak Aziah, S.Pd dan D olah(anak dari mak normah) .

\section{HASIL DAN PEMBAHASAN}

\subsection{Sejarah Kemunculan Dan Perkembangan Tari Jogi Menggunakan Penari Laki-Laki}

Tari Jogi diciptakan oleh Alm. Pak Basri dan Ibu Normah (88 Tahun). Keduanya adalah seniman melayu dari Pulau Panjang. Tak hanya Tari Jogi, keduanya pun kerap melakonkan Teater Melayu Klasik Mak Yong dan Joget Dangkong bersama temantemannya seperti: Makmur Mansur (Alm.), Anjang Atu (Alm.), Mat dan Bapak Saptono, Wasnuri. Pak Basri dan $\mathrm{Bu}$ Normah juga pula yang mengenalkan Budaya Melayu ini ke berbagai daerah dan kota-kota besar bahkan sampai ke negara-negara tetangga.

Tradisi seni pertunjukan di Asia Tenggara, Sebagian besar merupakan teater total yang sering kali melibatkan unsur musik, tari dan drama itu sendiri. Maka dari itu, penyatuan antara musik dan tari menjadi lebih tua di antara drama. Kondisi ini dapat dilihat dengan keberadaan tari-tarian Melayu yang bercampur dengan musik, sedangkan drama menjadi perkembangan selanjutnya (Brandon, 2003)

Sama halnya dengan Joget Dangkong, tari Jogi sendiri diciptakan sebagai tarian hiburan. Nama Dangkong dalam Joget Dangkong disebut sebagai perwujudan dari bunyi-bunyian instrumen gendang dan gung yang ditabuh, yakni 'dang' dan 'gung'. (Syafarudin, 2012). Hal ini membedakan tari Jogi dengan Joget Dangkong dalam hal penamaan. Istilah tari hiburan kerap kali dihubungkan dengan fungsinya sebagai tari sosial, namun pada perkembangannya komersialisasi terhadap seni pertunjukan ini tidak bisa diabaikan. Pasalnya, penyajian tari-tari hiburan semacam ini sering kali menerima permintaan dari masyarakat dengan menerima imbalan. Informasi semacam ini tidak terekam dengan baik, sebab hampir semua seni pertunjukan Melayu yang popular menjadi milik masyarakat segala kalangan hanya disebarkan secara lisan, kecuali faktor institusi tertentu mengarahkannya kepada bentuk tata Kelola komersial yang tepat. Hal ini juga dialami seperti Makyung di Malaysia yang dikelola secara komersial setelah Tengku Temenggung memberlakukan skim bayaran bagi senimannya. (Shafii, 2017)

Tari Jogi memiliki tujuh ragam gerak yang disebut dengan istilah rangkap, yakni jalan sembah, jalan kacak pinggang, jalan jumput bahu, menggesekkan kedua tangan, berkaca, bermain layang-layang dan gulung benang (Wibowo, 2019). Tari Jogi yang kini dikreasikan terinspirasi dari keindahan perempuan dan berbagai aktivitasnya saat menunggu kepulangan suaminya yang sedang melaut seperti meniru gerakan mencuci pakaian, mandi, dandan/besolek, melawa, sehingga tarian ini umumnya ditarikan oleh perempuan saja. Dahulu jumlah penarinya adalah 5 orang, sekarang jumlah penari nya tidak dibatasi hanya saja harus berjumlah ganjil. Kedua 
penyajian tersebut terdapat perbedaan pemaknaan pada gerak-gerak tarinya.

Informasi yang penulis peroleh dari hasil wawancara dengan maestro tari Jogi yaitu Normah, bahwa tari Jogi pada mulanya hanya disajikan dengan 4 penari perempuan dan 1 hari dunia Jogi, hari dunia Jogi merupakan syair pengantar menuju ke tari Jogi, dan biasanya disajikan dalam acara perkawinan, jikalau malam sudah sepi maka dilaksanakan lah tari Jogi, namun sekarang sudah banyak yang menyajikan dalam bentuk kreasi dengan jumlah penari lebih dari 4 orang, tari Jogi ini merupakan tarian yang diciptakan secara turun temurun dari mak Normah, bahkan tarian ini disajikan dengan musik live dan personilnya sendiri ialah cucu- cucu dari Normah. (wawancara dengan Normah, pada tanggal 30 November 2019).

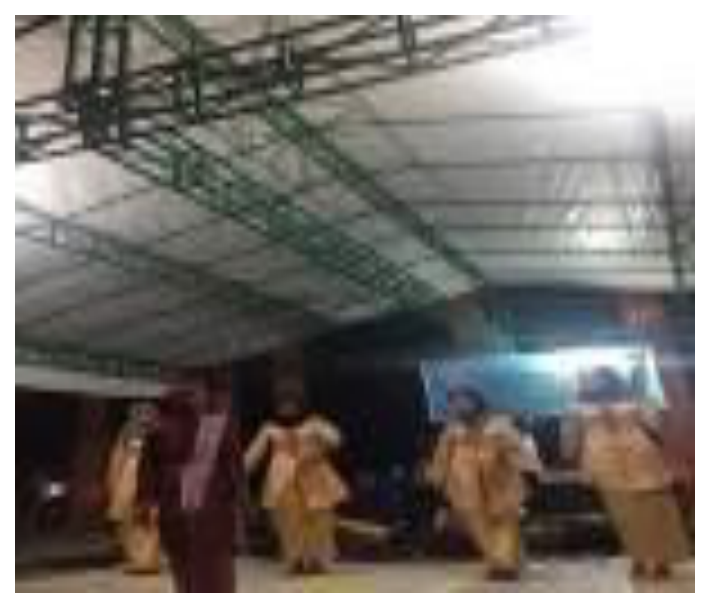

Gambar 1: Tari Jogi yang disajikan dengan 5 perempuan

(Sumber: Restu Gustian Asra, 30 November 2019)

Aziah selaku pakar tari tradisi Melayu yang juga merupakan Dosen Tari Etnis Melayu di Universitas universal mengatakan bahwa dahulunya Normah dan sang suami Alm. Basri yang merupakan seorang pemusik memiliki satu tim tarian Joget bersama Kepala Dinas Pendidikan dan diminta untuk tampil diacara Jakarta Fair pada tahun 1995. Pada saat berkumpul istirahat pemain musik dari Pulau Panjang yang merupakan anggota pemusik Alm. Pak Basri asik memainkan musik, sedangkan Normah menari dengan gerak yang diulang begitu-begitu saja, dan dari gerak Normah tadilah awal mulanya terciptanya tari Jogi kreasi yang di mana pada saat itu penari yang akan diberangkatkan ke Jakarta terdiri dari penari laki-laki dan perempuan sehingga tercipta lah tarian Jogi kreasi yang menggunakan penari laki-laki. Tarian ini cukup berkembang dikarenakan team joget Normah ini berhasil membawakan tarian ini dengan baik, dari sini menjadikan kota Batam terkenal dengan tarian Jogi, semisal Batam harus tampil dalam suatu acara pasti yang diminta tampil ialah tari Jogi. (wawancara dengan Aziah, pada tanggal 29 November 2019). Tom Ibnur selaku dosen tari di Institut Kesenian Jakarta tari Jogi berkembang di kecamatan Belakang Padang, Kota Batam, Prov. Kepulauan Riau dan gerak yang dilakukan pun mengutamakan pengolahan gerak bahu informasi ini dapat pada saat kunjungan mahasiswa Fakultas Seni, seni tari Universitas Universal ke Institut Kesenian Jakarta (Ibnur, 2019).

\begin{tabular}{lll}
\multicolumn{2}{c}{ Sebagai satu wilayah } & yang \\
mencakup berbagai "daerah & yang \\
sedang berkembang" & tidak \\
dikecualikan oleh sejarah & yang
\end{tabular}
menjadi faktor awal penciptaan sesuatu yang hingga saat ini menjadi dan ada karena tangan-tangan manusia yang punya rasa menghargai, suatu karya hendaknyalah diberikan apresiasi yang tinggi dan tetap 
dikenang hingga mati. Segala sesuatu yang tercipta pastinya berawal dari proses, dan manusia-manusia yang menghargai proseslah manusiamanusia yang akan paham terhadap diri sendiri yang siap maju menuju perkembangan, sehingga hal-hal yang telah ada sebelumnya tetap akan ada meski terjadi perubahan. Bahkan halhal bersejarah inilah yang nantinya akan menjadi suatu karakter di suatu daerah, salah satunya ialah tari Jogi yang berhasil ditetapkan menjadi induk/khas kota Batam (wawancara dengan Normah, pada tanggal 30 November 2019)

Tari Melayu sudah langka karena haus oleh perkembangan sosial ataupun gejala alamiah, terutama di daerah asalnya, sedangkan di lain pihak, ada gejala peninggalan kebudayaan Melayu yang sudah tersebar jauh dari daerah asalnya. Dalam pembicaraan sehari-hari tidak lagi ada keganjilan mengenai orkes Melayu, tari Melayu, teater Melayu, lebih-lebih sastra Melayu yang melampaui batas daerah asalnya itu.

$$
\text { Dilihat dari kepentingan }
$$

komunikasi, gejala pemekaran kebudayaan Melayu telah menumbuhkan rasa persatuan dalam kehidupan kebangsaan kita. Dalam sejarah, gejala ini dapat berkembang secara wajar dan telah menyadarkan kita bahwa kebudayaan Melayu memiliki daya komunikasi yang efektif, sehingga mudah mengalir dan diterima masyarakat.

Berbicara

tentang

perkembangan, tari Jogi merupakan salah satu contoh tarian yang berkembang karena faktor turuntemurun dari neneknya Normah yang hingga sekarang tarian ini tetap dilestarikan oleh cucunya, namun pak dorani selaku pendiri sanggar budaya melayu Pantai Basri mengatakan rasa nya tidak cukup kalau hanya keluarga kami saja yang berperan aktif dalam perkembangan tari Jogi ini, kami sangat berharap kepada semua mahasiswa universitas universal siap andil dalam mengembangkan tari Jogi ini, paparnya pada saat kegiatan PKM bersama maestro tari Jogi (wawancara dengan Dorani, Pada tanggal 30 November 2019). Terkait penelitian mengenai adanya penari laki- laki pada tari Jogi ini belum terlihat jelas perkembangannya, namun peneliti pernah menyajikan pada pagelaran seni tari semester 2 Humartnity yang merupakan mata kuliah tari etnis melayu yang diampu oleh Aziah, peneliti merasa ini juga merupakan langkah untuk perkembangan tari Jogi yang menggunakan laki-laki. Wawancara bersama maestro tari Jogi yaitu Normah juga kami dapatkan informasi bahwa tari Jogi yang menggunakan laki-laki ini tidak dapat diterima oleh masyarakat setempat karena motif gerak yang ada dianggap vulgar, sehingga keterbatasan pada pengembangan berdampak pada tari Jogi ini melalui adanya standar-standar penggunaannya.

Anggapan vulgar ini diperkirakan berkaitan dengan jenis tari tandak atau joget atau ronggeng yang dalam khazanah seni pertunjukan Melayu merupakan salah satu dari bentuk tari sosial/ pergaulan sekaligus hiburan. Hal ini dijelaskan oleh T. Luckman Sinar dalam klasifikasi tari Melayu ke dalam empat jenis yaitu kelompok tari yang bersifat magis-religius, kelompok tari perang, tari pertunjukan, dan kelompok tari-tarian ronggeng. (Murgiyanto, 2016).

Seni pertunjukan yang pewarisannya bersifat lisan memberi peluang terhadap penafsiran yang 
berbeda antara guru dan murid, hingga seringkali terjadi bentuk-bentuk variatif sebagai hasil dari tindakan penambahan maupun pengurangan. (Jaeni, 2012). Kondisi seperti ini merupakan hal lazim dalam perkembangan seni pertunjukan yang diturunkan secara lisan, bahkan informasi tertulis mengenai tari Jogi tidak banyak dibuat dan dipublikasikan.

\subsection{Tari Jogi yang Melibatkan Komposisi Duet Berpasangan}

Bentuk penyajian baru yang disusun berdasarkan pengembangan kreatif berorientasi pada nilai vital seni pertunjukan itu sendiri, diantaranya fungsi awal kemunculannya yang ditunjang dengan dinamika kebutuhan masyarakatnya. Kondisi semacam ini melibatkan jenis-jenis tindakan kreatif yang mengacu pada pokok revitalisasi. Rahayu Supanggah membedakan jenisjenis revitalisasi antara lain rekonstruksi, refungsionalisasi, representasi, reinterpretasi, reformasi, reorientasi, dan rekreasi. Konteks perubahan bentuk penyajian tari Jogi menurut penjelasan di atas merupakan bentuk reformasi, yakni bentuk penyajian dari yang lama ke yang baru sesuai dengan kebutuhan terhadap aspek tempat dan waktunya (Warto,2014). Afitri Susanti selaku perwakilan juri dari dinas Kebudayaan Prov. Kepulauan Riau pada saat pemilihan Duta Budaya Prov. Kepulauan Riau menerangkan sedikit bahwa maksud dari tari Jogi sendiri ialah tari berpasangan yang dimana wanita yang suka menggoda seorang laki-laki (wawancara dengan Afrita Susanti, pada tanggal 26 Oktober 2018).

Penyesuaian ini tentu mempertimbangkan aspek bentuk dan isi, yang menyatu sebagai bagian dari perwujudan aspek teks dan konteksnya (Hadi, 2014). Maka, bentuk penyajiannya memungkinkan menampilkan peran laki-laki sebagai masyarakat nelayan di Batam, Kepulauan Riau. Esensi pokok dari suatu kesenian sebagai salah satu unsur kebudayaan menurut Koentjaranigrat berawal dari kebutuhan naluri manusia akan keindahan (Martiara, 2012). Maka berdasarkan hal tersebut, penyusunan tari Jogi dengan melibatkan penari laki-laki tentu mempertimbangkan aspek estetika dan artistiknya.

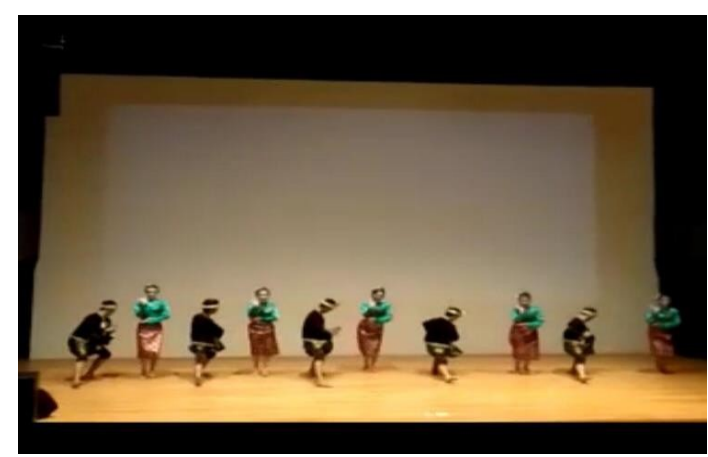

Gambar 2: Tari Jogi yang disajikan dengan penari laki-laki (Tari Jogi kreasi)

(Sumber: Restu Gustian Asra, 25 Mei 2019)

Pada tari Jogi memang seharusnya hanya penari perempuan yang terlibat penuh, namun di sisi lain adanya faktor kebutuhan sehingga penari laki-laki juga sangat di perlukan, namun akan beda jumlah keterlibatan dari penari laki-laki dan perempuan, pastinya kita sendiri akan paham mana yang harus diikuti agar penyajian karya tari Jogi ini sesuai. Selanjutnya informasi kembali dari Normah selaku maestro tari Jogi, beliau mengatakan bahwa tari Jogi yang disajikan dengan penari laki-laki ialah tari Jogi kreasi yang dinamakan tari tombak namun menggunakan rentak tari Jogi. Dinamakan dengan tari tombak karena motif gerak yang disajikan 
menggunakan gerak layaknya sedang menombak.

Sama dengan halnya penjelasan yang dimana tarian Jogi yang hanya menggunakan perempuan, bahwa sang istri yang menunggu sang suami melaut. Pada dasarnya konsep tarian ini sama namun yang membedakan ialah biasanya laki-lakinya tidak dimunculkan, namun kali ini disajikan dengan dimunculkannya laki laki, sehingga disebut tari Jogi kreasi yang dinamakan tari tombak.

Penambahan unsur penari lakilaki dengan gerak khasnya dalam koreografi ini mengacu pada kreativitas yang dimengerti sebagai penyesuaian terhadap apa yang dimengerti masyarakat sebagai 'apa yang baik'. Hal ini biasa juga disebut sebagai ideology, yang kemudian memberi implikasi terhadap nilai-nilai kehidupan sosial di masyarakat yang umuya terkait dengan aspek ekonomi, demografi, pendidikan, dan teknologi. (Jaeni, 2012)

\subsection{Fungsi Tari Jogi di Masyarakat}

Berbicara tentang karya tari dilingkungan masyarakat, artinya mengacu pada karya tari sebagai tindakan sosial di mana Tari Melayu sebagai kebudayaan pesisir telah mengalir dan menelusuri pantai Nusantara, ibarat pengantar komunikasi secara merata. Terus mengalir kemudian lebur dan mengendap dalam kehidupan. Kehidupan yang sangat terasa dalam diri dan raga secara menyeluruh, sedangkan dalam unsur gerak bisa dirasakan melalui karakter dan sifat gerak tarinya. Komunikasi secara merata ini dalam tarian mempunyai daya yang lebih wajar dalam hubungan dan pergaulan antar manusia. Sifatnya yang begitu sensitif dalam komunikasi kebudayaan ini juga dapat membawa faktor negatif. Misalnya, cepat dicintai, tetapi cepat pula dilupakan

Untuk memahami tindakan sosial yaitu karya seni pertunjukan hubungannya dengan masyarakat itu, ada beberapa teori untuk mempertajam analisis ini, antara lain teori aksi atau tindakan (action theory) yang dikembangkan oleh Talcott Parson dengan mengikuti karya Weber. Pandangan teori ini menganggap bahwa manusia dalam hal ini si pencipta merupakan aktor atau seniman yang aktif-kreatif, bersifat voluntarism, yaitu kesukarelaan, kebebasan individu (si pencipta) atau seniman melakukan "tindakan (volunteering for action), dalam arti menetapkan cara, alat dari sejumlah alternatif, yang tersedia dalam rangka mencapai tujuan yakni menciptakan seni pertunjukan itu. (Hadi, 2012)

Kendati menciptakan sesuatu yang sifatnya kreasi tentu tak bisa mengabaikan aspek historis dan peristiwanya di masa kini. Hal ini berkaitan dengan pemikiran Weber yang menggunakan pendekatan logisnya (verstehen) yang mengarahkan pada hubungan sinkronik-diakronik. Hubungan ini memahami adanya kausalitas historis yang menyangkut pertanggung jawaban akibat konkret dari sebab yang konkret. Di sisi lain, mencermati perubahan yang bernilai historis namun tidak meninggalkan semangat zamannya (Hadi, 2007).

Bentuk penyajian tari Jogi yang baru dapat dibedah menggunakan pendekatan analisis koreografi yang meliputi segala sesuatu yang tampak, dapat dibaca dan dianalisis secara tekstual, sehingga susunan gerak tarinya dapat dikomunikasikan kepada penonton. (Widyanarto, 2019) 
Jogi berperan sangat aktif dalam kehidupan masyarakat tidak lain menjadi salah satu pertunjukan hiburan, semisalkan dalam acara perkawinan, tarian ini dapat ditampilkan di akhir acara jikalau malam telah sepi, dan penari Jogi berteriak "Jogi" (menari) maka 4 penari dan 1 hari dunia Jogi akan mulai masuk terlebih dahulu untuk mengambil perhatian masyarakat untuk ikut menari bersama. Dalam hal ini terlihat jelas bahwa tari Jogi memang erat kaitannya dengan masyarakat pada awal mulanya tari ini disajikan, seiring kehidupan nyata berlalu dan terus menerus terjadinya perubahan dunia, maka timbul lah faktor-faktor yang menyebabkan perubahan fungsi pada tari Jogi, faktor yang paling utama menurut peneliti karena kurangnya publikasi secara materi maupun praktik. Dalam hal ini fungsi tari Jogi berubah tidak hanya ditampilkan di acara pernikahan melainkan dapat dijadikan tarian hiburan yang dapat ditampilkan diacara acara besar sebagai tari pembuka dan menjadi salah satu mata kuliah tari etnis melayu di fakultas seni, program studi Seni Tari, Universitas Universal, Batam.

Faktor lain yang mendukung seni pertunjukan tradisional mengalami perubahan fungsi seperti tari Jogi ini adalah faktor sosial, faktor ekonomi, dan sistem pewarisannya, sebab hal ini juga telah dialami pada kesenian Melayu, yakni tari Gayong Otar-otar di Malaysia. (Salman, 2018)

\section{KESIMPULAN}

Tari Jogi awal mulanya hanya lah perempuan, dengan jumlah penari sebanyak 5 orang, yang didalamnya terdapat 1 orang hari dunia Jogi, yang merupakan syair pengantar menuju ke tarian Jogi. Adanya penari laki-laki pada saat itu dikarenakan kebutuhan, dan disajikan dalam bentuk kreasi yang dinamakan tari tombak, namun menggunakan rentak tari Jogi. Perihal cerita dari tari Jogi ini tidak berbeda antara tari Jogi yang menggunakan laki- laki dengan tidak menggunakan laki-laki, sama saja hanya saja dihadirkan penari laki-lakinya yang sedang menombak dan ditunggu oleh sang istri.

Dimasa sekarang ini, tari Jogi yang asli berkembang baru hanya di lingkungan keluarga Normah, yang sekarang dilestarikan oleh cucu-cucu Normah, dan pastinya keluarga Normah memiliki harapan agar tidak hanya keluarganya saja yang melestarikan, namun semua orang yang terkait pencinta seni khususnya seni tari juga dapat ikut serta di dalamnya. Hal ini merupakan wujud pelestarian yang kuat sehingga akan mudah mengalami perkembangan dan tetap akan diingat dan jadi bagian dari kegiatan masyarakat. Keberadaan tari Jogi di masyarakat akan senantiasa dikenal, dengan keunikannya juga dapat memberikan sentuhan kepada masyarakat bahwa tari juga merupakan tindakan sosial, yang juga berfungsi di dalam kegiatan sosial masyarakat, dahulu sebagai penghibur diacara pernikahan, dan dengan seiring perkembangan dunia menjadikan tari Jogi berubah fungsi sebagai media edukasi tari tradisi dan tetap menjadi penghibur tidak hanya di acara perkawinan, melainkan penghibur diacara- acara resmi.

\section{DAFTAR PUSTAKA}

Al Farisi, Salman., Muhammad Fazli Taib Saearani. (2018). "Form and Factors affecting the Development of gayong Otar- 
Otar Dance in the Malay Community of Terengganu, Malaysia." International Journal of Academic Research in Business and Social Sciences.

Brandon, James R. (2003). Jejak-jejak Seni Pertunjukan di Asia Tenggara. Bandung: P4ST UPI. Hadi, Y.S. (2014). Koreografi: BentukTeknik-Isi. Yogyakarta: Cipta Media. . (2012). Seni Pertunjukan dan Masyarakat Penonton. Yogyakarta: Perpustakaan Nasional: Katalog dalam terbitan(KDT).

. (2005). Sosiologi Tari. Yogyakarta: Penerbit Pustaka

Jaeni. (2012). Komunikasi Estetik: Menggagas Kajian Seni dari Peristiwa Komunikasi Pertunjukan. Bogor: IPB Press. Martiara, Rina. (2012). Nilai dan Norma Budaya Lampung dalam Sudut Pandang Strukturalisme. Yogyakarta: Badan Penerbit ISI Yogyakarta.

Murgiyanto, S. (2016). Seni Tari Melayu: Struktur dan Refleksi Keindahan. dalam Koentjaraningrat, Masyarakat Melayu dan Budaya Melayu dalam Perubahan. Yogyakarta: Balai Kajian dan Pengembangan Budaya Melayu.

Soedarsono, R.M. (1999). Metodologi Penelitian Seni Pertunjukan dan Seni Rupa. Bandung: Masyarakat Seni Pertunjukan Indonesia.

Syafarudin. (2012). Alam Melayu: Dari Ingatan ke Kenyataan, Esai Foto; Revitalisasi Budaya Melayu 2012. Tanjungpinang: Dinas Kebudayaan dan
Pariwisata

Tanjungpinang

Kepulauan Riau.

Syafii, Hardy A. S. (2017). Makyung,

Pelbagai Perspektif tentang

Teater Tradisional Malaysia.

Kuala Lumpur: Dewan Budaya dan Bahasa.

Warto. (2014). "Revitalisasi Kesenian Kethek Ogleng untuk Mendukung Pengembangan Pariwisata di Kabupaten Wonogiri". Jurnal Paramita, Vol.24, No.1- Januari.

Wibowo, Denny Eko. (2019). Studi Laban Tari Jogi. Jurnal Seni Tari Unnes, Vol 8 No 2.

Widyanarto. (2019). Revitalisasi Silat Tradisi Melayu Tari Silat Bendera, Bentan Penao, Bintan, Kepulauan Riau. Kepulauan Riau: Khazanah Ilmu Berazam, Vol 2, No 1, Maret.

Yulianti, M., Dewi. (2014). Seni Budaya kelas $X$. Bandung: HUP. 